\section{Estudo da prevalência de úlceras perianais em pacientes com AIDS e fatores associados}

Lesões ulceradas perianais são comumente observadas em pacientes com AIDS em estágio avançado. Nesta população, essas úlceras podem aumentar progressivamente de tamanho, causando dor e desconforto. Embora o aspecto clínico seja sugestivo de infecção pelo vírus herpes simples, outras causas podem ser encontradas. Não há descrição na literatura sobre quais variáveis estariam associadas à presença dessas lesões. As úlceras mucocutâneas de etiologia herpética podem ser diagnosticadas por isolamento viral de material coletado das lesões. Mais recentemente, a reação em cadeia pela polimerase tem sido empregada em alguns estudos no diagnóstico de lesões genitais herpéticas e detecção de excreção assintomática na região anogenital. Com a finalidade de estimar a prevalência de úlcera perianal em pacientes com AIDS em fase avançada de imunodepressão, foram entrevistados e examinados durante oito meses 272 pacientes internados no Instituto de Infectologia Emílio Ribas. Encontrou-se prevalência de $9,2 \%$ de úlcera perianal. As variáveis associadas à presença da lesão, após análise multivariada, foram história de candidíase esofágica e história de úlcera perianal. Presença do vírus herpes simples nas úlceras perianais foi documentada em 12/23 (52,2\%) dos casos por isolamento viral e em $22 / 23(95,6 \%)$ casos pela técnica de reação em cadeia pela polimerase.

\section{Ulcerated perianal lesions in AIDS patients: prevalence and associated factors}

Ulcerated perianal lesions are commonly observed in patients with AIDS, especially in advanced HIV disease. These lesions may continue to enlarge peripherally, causing pain and discomfort. Although herpes simplex virus has been pointed out as the main etiologic agent, some other causes can be associated with perianal ulceration. Information is scant about risk factors associated with perianal ulcers in AIDS patients. Mucocutaneous ulcers caused by herpes simplex virus are usually diagnosed by viral culture from a swab sample obtained from the lesion. Polymerase chain reaction has been used to diagnose genital herpetic ulcers and detect asymptomatic excretion in the anogenital region. To estimate the association of ulcerated perianal ulcer with advanced HIV disease, for 8 months 272 patients hospitalized at the Instituto de Infectologia Emílio Ribas were studied: perianal ulceration was found in $9.2 \%$ of patients. In multivariate analysis, the conditions significantly associated with the presence of perianal ulcer were history of esophageal candidiasis and history of perianal ulcer. Herpes simplex virus was detected by polymerase chain reaction in $22 / 23$ patients (95.6\%) and by viral culture in 12/23 (52.2\%).

\author{
Maria Cláudia do Nascimento \\ Tese apresentada à Faculdade de Medicina da \\ Universidade de São Paulo para obtenção \\ do Título de Mestre.
}

São Paulo, SP, Brasil, 1999.

Recebido para publicação em 25/6/99. 